\title{
Ovarian tumours of Wolffian or allied nature: their place in ovarian oncology
}

\author{
PE HUGHESDON \\ From the Department of Morbid Anatomy, School of Medicine, University College London, University \\ Street, London WCIE 6JJ
}

SUMmARY Two unusual ovarian tumours thought to be of Wolffian identity, one of them malignant, are described. They showed packed combinations of adenopapillary, tubular, trabecular and diffuse patterns, a sharp and generalised periodic acid-Schiff (PAS)-positive basement membrane and areas of elastic network. A review of published Wolffian tumours at various sites suggests that the prototypes of the two tumours occur chiefly in the cervix and broad ligament. The significance of Wolffian tumours and their differentiation from arrhenoblastoma and serous tumours is discussed.

In an earlier article $^{1}$ we described two female adnexal Wolffian tumours, resembling the 10 previously reported. ${ }^{2} 3$ We noted a morphological overlap with arrhenoblastoma (androblastoma, Sertoli-Leydig cell tumour) and that some may be oestrogenic.

One reported tumour arose in the rete ovarii. ${ }^{2}$ In 1974 Dr Scully kindly sent the author sections of a similar ovarian tumour, which resembled our second case, and has since collected others. However, as authentic Wolffian tumours have varied in structure, ${ }^{1}$ an ovarian case might imitate many structural protypes. The present article describes two such cases, one of them polymorphic, the other a reconsideration of our previous case 1 .

\section{Case reports}

CASE 1

A 79-year-old woman, para $2+0$, had had slight constipation and retention of urine for one day. Her only noteworthy past history was an attack of cholecystitis. She had had the menopause at the age of $50 \mathrm{yr}$ and no bleeding since. On examination she was found to be fit, non-hirsute and mildly hypertensive (170/100), with a mass in the lower abdomen and pouch of Douglas. At operation on 24 July 1959 , the only pelvic abnormality present was a leftsided ovarian tumour impacted in the pouch of Douglas. This was removed, together with the right adnexa. Convalescence was complicated by a urinary tract infection.
She was readmitted on 26 August 1960, aged $80 \mathrm{yr}$, with a history of weight loss and upper abdominal pain for $6 \mathrm{wk}$ and nausea, vomiting and jaundice for $3 \mathrm{wk}$. She was tender in the right hypochondrium and had a mass in the pouch of Douglas. A radiograph showed no opaque masses in the gallbladder region. After some initial improvement she became disorientated, with increasing jaundice and retention of urine; she died on 16 September 1960.

\section{Pathology}

The left ovarian tumour $(14 \times 9 \times 8 \mathrm{~cm})$ was ovoid, with a partly rough but intact capsule and an attached tube. About half consisted of a locule containing blood-stained clot and half of soft solid tissue from which six blocks were made. The right ovary was small and unremarkable.

Microscopy The tumour was pleomorphic with four types of histological appearance.

\section{Type 1}

Throughout the tumour but chiefly at the periphery and in the broader septa there were inactive serous locules with or without papillae (Fig. 1). The lining epithelium was flat, hobnail or cubical, with scanty cytoplasm, occasional differentiation into secretory and ciliated forms, large pale ovoid nuclei and virtually no mitoses. The lumina and cell borders, but not the cytoplasm, showed diastase-fast periodicacid Schiff (PAS)-positive material, some of which stained with alcian blue. A fine PAS-positive basement membrane was present, becoming ill-defined under the flatter cells. 


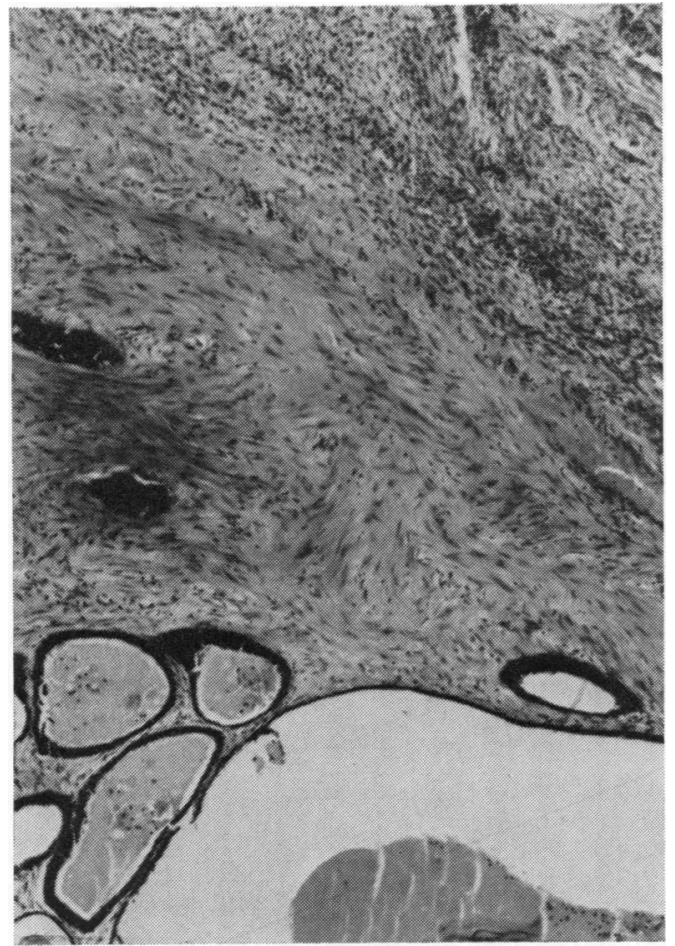

Fig. 1 Case 1, area 1. Dark inactive serous spaces lying in hyperplastic mesovarian muscle, with ovarian hilar stroma above. Haematoxylin and eosin $\times 50$
Type 2

This type was present in three blocks and resembled that reported in broad ligament tumours. It formed ovoid areas in epithelial continuity with bordering locules of the first type. It consisted of clustered or interwoven tubules with occasional papillae, often radiating with dichotomous branching from a central space containing cellular debris. Some of the clusters formed lobules, clothed peripherally by diffuse mesenchyme (Fig. 2) or fine cords (Fig. 3), but most blended into a continuous mass. The lining cells were dark cubical or columnar with scanty protruding cytoplasm and large pale ovoid nuclei. In some areas mesenchyme predominated and contained occasional adenopapillary spaces and mesothelioid vesicles (Fig. 4). The average mitotic count was 1.4 per high power field $(\mathrm{HPF} \times 450)$ in epithelial areas (50 fields) and 3.0 in the mesenchyme ( 20 fields). A few gland lumina showed scanty PASpositive material, negative with alcian blue. A fine sharp PAS-positive basement membrane was present round the glands, continuing into the diffuse areas to divide much of them into elongated islands. The reticular pattern was similar but in places pericellular. Elastic staining after permanganate oxidation $^{4}$ also showed a fine network in some areas.

\section{Type 3}

This was present throughout the tumour and appeared to develop gradually from the first. It was

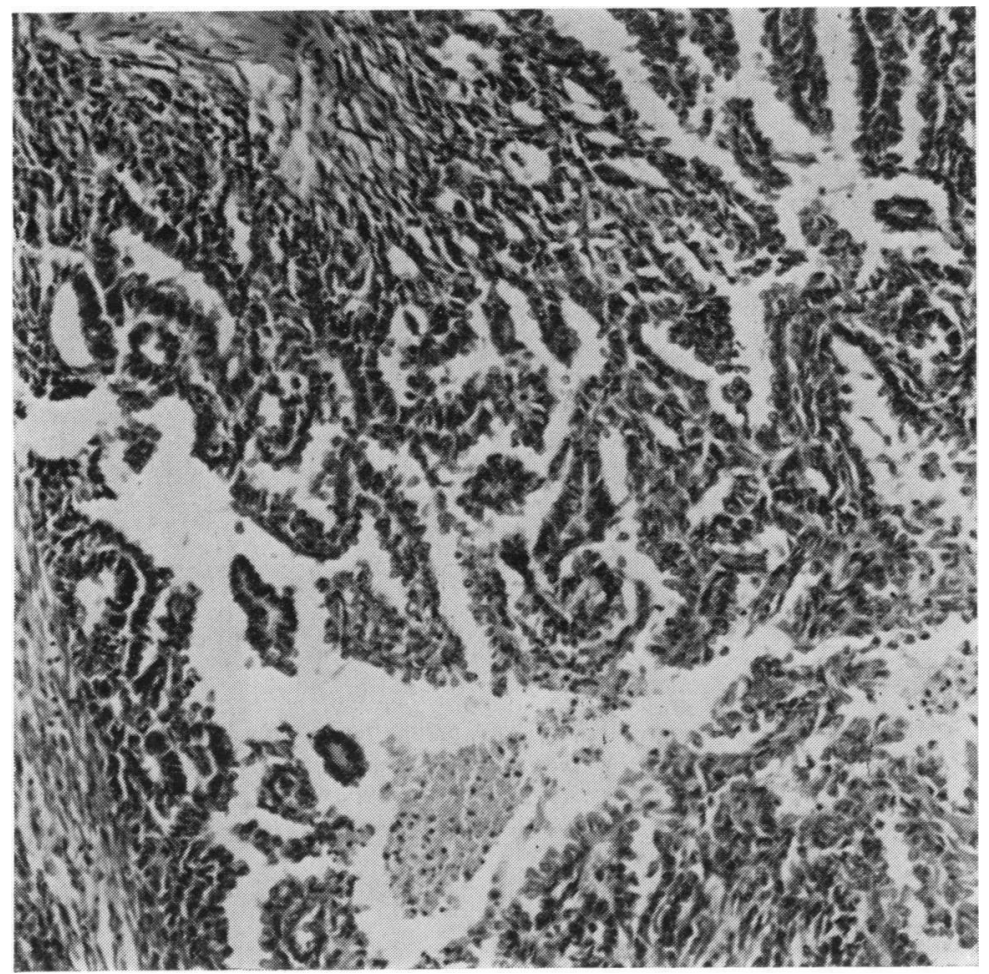

Fig. 2 Case 1, area 2. Branching tubules with dark pouting epithelium radiating from a central space and clothed peripherally by mesenchyme. Haematoxylin and eosin $\times 125$ 


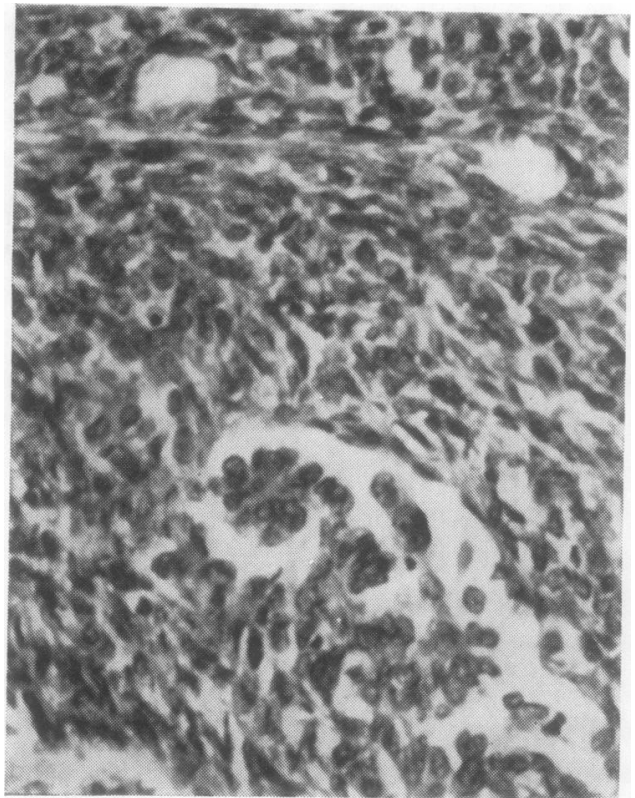

Fig. 4 Case 1, area 2. Cellular mesenchymal area containing small adenopapillary spaces and tiny mesothelioid vesicles. Haematocylin and eosin $\times 275$

markedly lobular with three main patterns (Fig. 5): locules with papillae (below); clusters of small dark gland spaces (centre); and packed intralocular adenopapillary formations (above) which often showed woven, looped or sinuous outlines (Fig. 6). The tubules were small, some being minute and solid, and often formed ovoid clusters (Fig. 7). Others fused to solid areas, either as loose aggregates
Fig. 3 Case 1, area 2, Similar but less ordered tubules bordered by epithelial cords. Haematoxylin and eosin $\times 140$

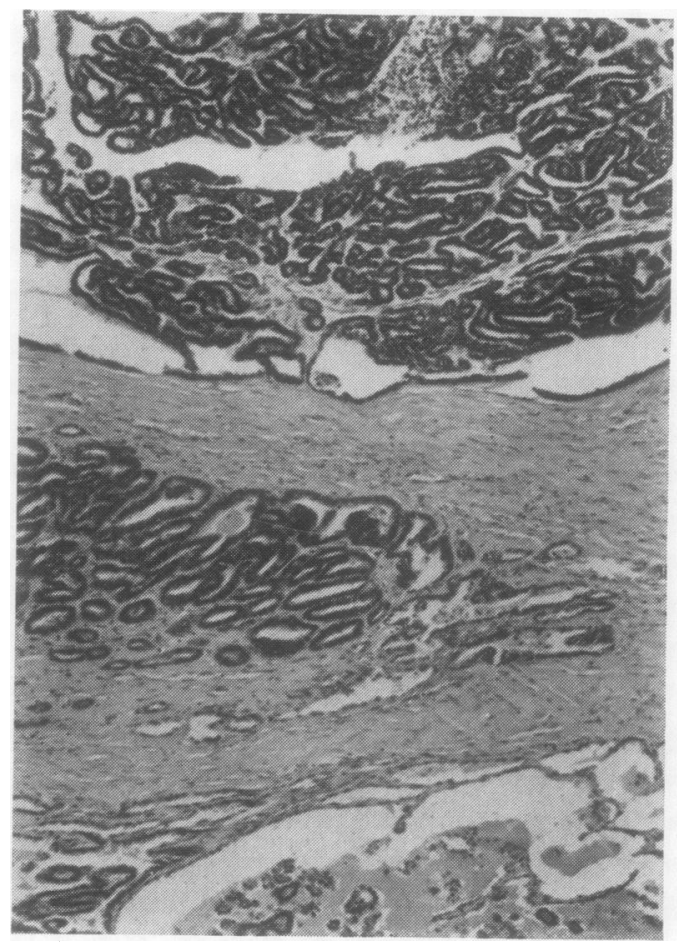

Fig. 5 Case 1, area 3. The three main patterns. Serous locules with papillae below; clustered small gland spaces centrally; and intralocular woven adenopapillary formations above. The central and upper areas show patterns seen in cervical Wolffian tumours. Haematoxylin and eosin $\times 60$ 


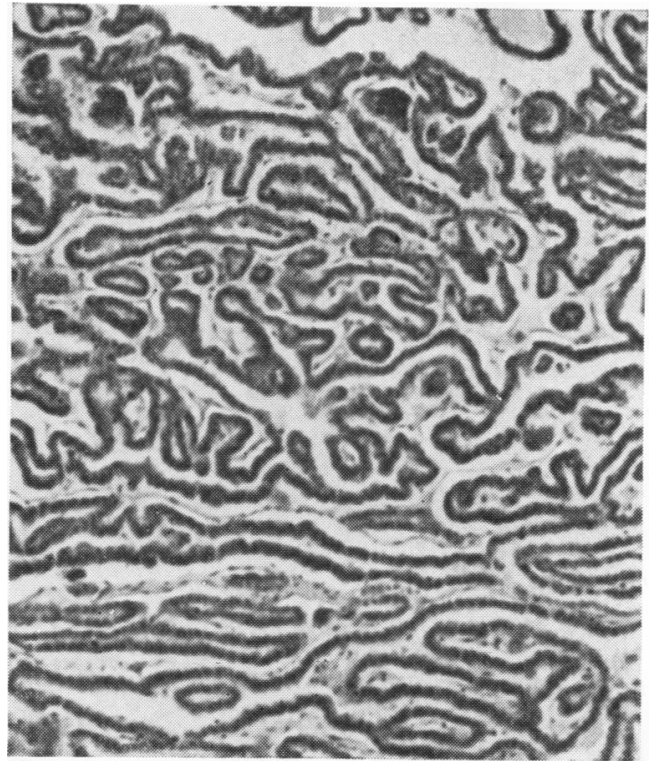

Fig. 6 Case 1, area 3. Luxuriant intralocular adenopapillary area with mostly single-layered epithelium woven into complex sinuous patterns. Haematoxylin and eosin $\times 135$

of tiny islands and cords or as condensed palisaded masses.

Most of the epithelium was cubical and singlelayered, with large ovoid vesicular nuclei, scanty cytoplasm with indistinct boundaries and a smooth luminal border. Many lumina contained exfoliated cells, sometimes swollen and pale, and a little PASpositive material, occasionally staining with alcian blue. There was a fine sharp PAS-positive basement membrane round the tubules (Fig. 8). and solid areas, but within the latter it was interrupted or absent. There was a weak and incomplete elastic network, a few tiny stromal concretions and no mesenchymal areas. The mitotic count per HPF was 2.3 in a purely papillary area (10 fields), $2 \cdot 1$ in an inactive glandular area as in Fig. 5 (10 fields) and $5 \cdot 2$ in the rest ( 60 fields).

\section{Type 4}

This was present in two blocks and was continuous with the third type. It contained large glands lined by columnar epithelium with large ovoid nuclei and cytoplasm usually scanty but occasionally ample and ciliated. Some glands were single-layered and roughly endometrioid, with frequent subnuclear vacuoles. Most were stratified, of varying size, clustered and either apposed or fused with each other and with branching epithelial cords (Fig. 9), often continuing into a dilated single-layered space. PAS showed plentiful positive material in these spaces, a little at the luminal border of the others and a thin sharp basement membrane. The stroma between these structures was mostly cellular and occasionally blended with them. Mitotic counts were 4.0 in the epithelium ( 20 fields) and 1.5 in the stroma (10 fields) per HPF.

The capsule of the tumour consisted of about three fifths fibrous connective tissue with a few small

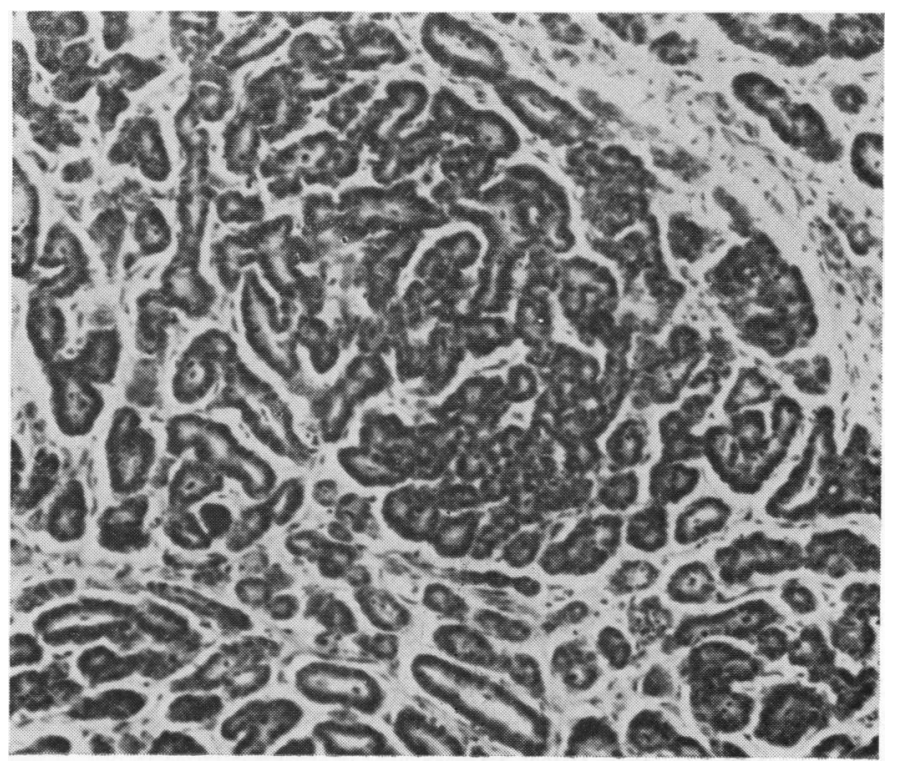

Fig. 7 Case 1, area 3. Clusters of tiny gland spaces and occasional solid islands forming ovoid lobules. The tumour growth in Figs. 5, 6 and 7 would not be out of place in renal adenomas or carcinomas. Haematoxylin and eosin $\times 125$ 

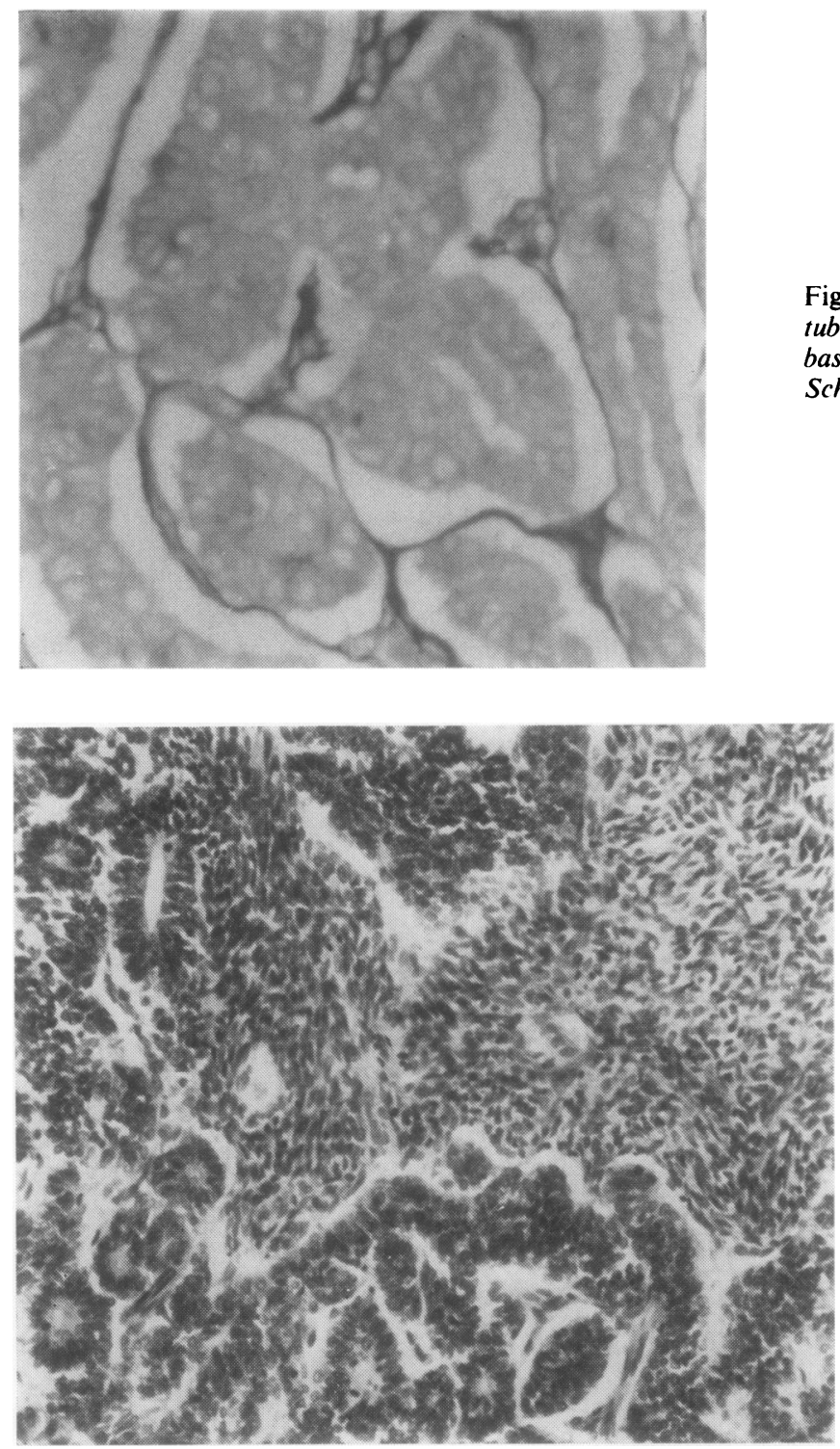

Fig. 8 Case 1, area 3. Packed tiny tubules with sharp PAS-positive basement membrane. Periodic acidSchiff and methyl green $\times 380$
Fig. 9 Case 1, area 4. Clusters of interconnected stratified glands and cords and cellular mesenchyme. Note the similiarity of pattern to that seen in a nephroblastoma. Haematoxylin and eosin $\times 145$ seams of ovarian cortex and two fifths hypertrophic mesovarian smooth muscle. Attached mesosalpinx and broad ligament were separately identified. Tumour reached to $0.2 \mathrm{~mm}$ from the surface, consisting mainly of inactive serous locules in the muscle (Fig. 1). Most of the septa were poorly cellular with a little smooth muscle near the hilus and some patches of ovarian stroma, one of them at the mesovarian border of the tumour.

There were no lutein foci or vascular permeation. Both tubes were senile, with low epithelium. The right ovary was atrophic with a nodular cortex, germinal inclusion cysts, surface tufts and no tumour of any kind.

Necropsy showed the body of a thin jaundiced non-hirsute elderly woman with purulent bronchitis. At the porta hepatitis was a firm mass $8 \mathrm{~cm}$ in diameter, containing a shrunken gallbladder and adherent to the liver. A deposit of tumour $5 \mathrm{~cm}$ in diameter was found on the outer surface of the ascending colon $5 \mathrm{~cm}$ above the ileocaecal valve and a somewhat larger, partly haemorrhagic mass between the uterus and rectum, adherent to both. The mass in the porta hepatitis was an adeno- 
carcinoma with glands and solid areas, randomly scattered in an extensive fibrous stroma (Fig. 10). The cytoplasm was ample and mostly pale, occasionally mucinous. Mucus secretion was abundant and equally positive with PAS and alcian blue. Some larger glands showed a weakly PAS-positive basement membrane. Tumour was present in the gallbladder wall and mucosa and in the edge of the liver. The origin was thought to be either the gallbladder or an adjacent large bile duct.

The mass on the colon was histologically similar and showed vascular permeation. The mass in the pouch of Douglas was thought to be ovarian. It consisted of sheets of small dark cells with scanty cytoplasm and occasional tiny acini and cords, at one point Sertoliform, with a weakly PAS-positive basement membrane in some areas. There were a few foci of vascular permeation. The uterus showed a hypoplastic endometrium, with many cystic and some pseudostratified glands and an occasional mitosis.

Blocks from the original ovarian tumour, the biliary tumour found at necropsy and metastatic tumour on the colon and in the pouch of Douglas were stained by Dr Eadie Heyderman for carcinoembryonic antigen (CEA) and epithelial membrane antigen(EMA), ${ }^{5}$ using an indirect immunoperoxidase technique. ${ }^{6}$ All the blocks contained EMA, but only the biliary carcinoma and the metastasis on the colon contained CEA. The immunocytochemical findings support the belief that the patient had two different primary tumours.

CASE 2

A 52-year-old woman, para $0+0$, had had frequency of micturition for some months, no noteworthy past history and no hirsutism. At operation on 10 December 1957, a grapefruit-sized tumour of the right ovary was removed, together with the uterus and opposite adnexa. The patient was free of recurrence in May 1977, full details being available in an earlier report. ${ }^{1}$

\section{Pathology}

The right ovarian tumour $(15 \times 12 \times 8 \mathrm{~cm})$ was ovoid, soft, solid and largely intraligamentous, but continuous with the lateral pole of the right ovary which spread out to form a plaque on its surface.

\section{Microscopy}

The endometrium showed an active cystic hyperplasia. The bulk of the tumour was described previously ${ }^{1}$ and consisted of packed glands, cords and diffuse areas (Fig. 11) resembling the second area of case 1 but with more corded and less diffuse growth. There was a mitotic rate of $0 \cdot 1$ per HPF ( 20 fields) and a few small areas of fine elastic network.

Tumour continued into the ovarian medullary tissue of the capsular plaque to $1 \mathrm{~mm}$ from the outer surface. At this site the septa were thick and collagenised and the tumour disposed in broad overlapping fusiform seams. These ran tangentially into the main tumour mass internally and the ovarian medullary tissue externally, being entered by a narrow seam of cellular medullary stroma. At three points in this area clusters of Sertoliform cords were seen with transversely directed cells and solid islands with elongated cells (Fig. 12). In cords elsewhere the cells were variously orientated (Fig. 11).

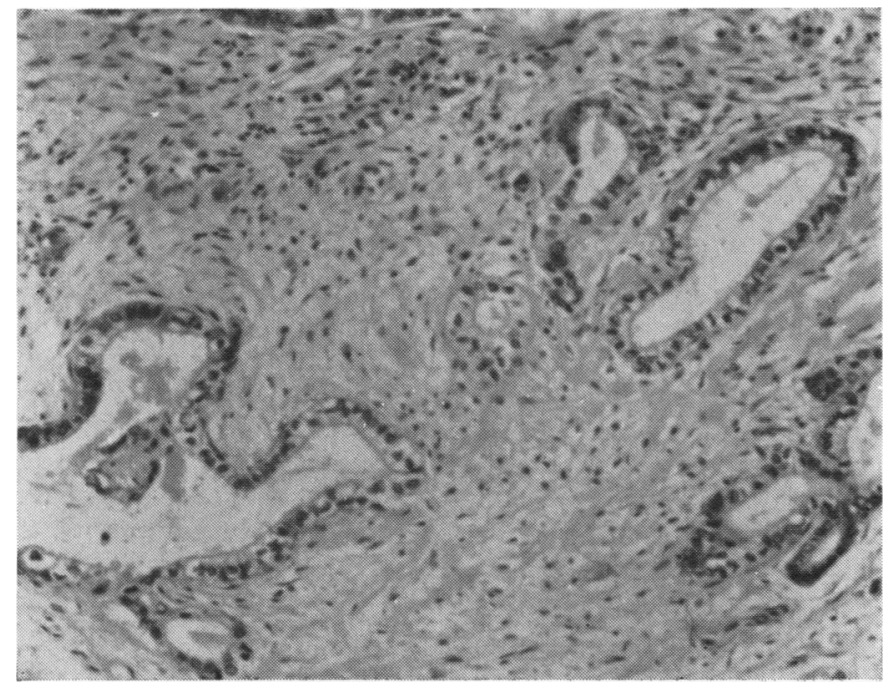

Fig. 10 Case 1, necropsy. Biliary carcinoma from porta hepatitis with irregular pale gland spaces, solid islands and fibrous stroma. Haematoxylin and eosin $\times 140$ 


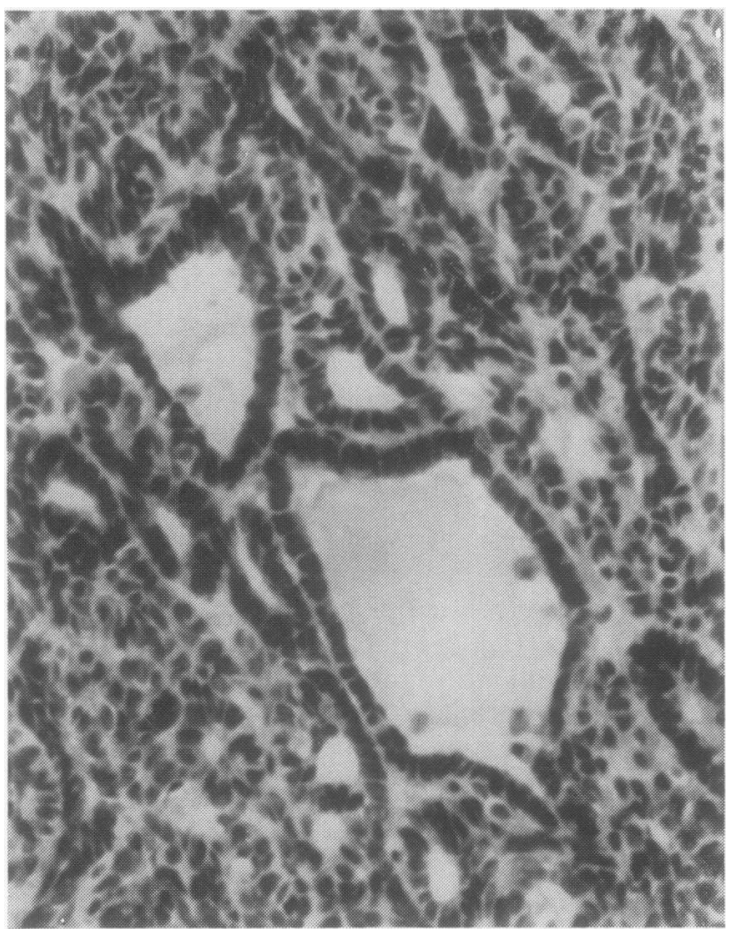

Fig. 11 Case 2. Clusters of glandlike spaces and cords with variable cell orientation. Heamatoxylin and eosin $\times 300$

\section{Discussion}

In case 1 the ovarian and biliary tumours were separate, differing in pattern, cell type, mucin and antigens. Moreover, a secondary ovarian tumour of this size would probably show vascular permeation and contralateral microscopic secondaries. The luxuriant growth and relatively aggressive behaviour of the ovarian tumour reflect the mitotic rate. This was many times higher than in case 2 and in previously reported broad ligament tumours, ${ }^{2}$ and is uncommon in ovarian carcinoma where it carries a poor prognosis.?

Case 2 was first judged to be ovarian from its continuity with the ovary and later to be a broad ligament Wolffian tumour from its histology.1-3 The later identification of a similar ovarian tumour favours the first view. The tangential relation of the collagenised seams to the ovarian cap and tumour periphery also indicate an ovarian origin. ${ }^{8}$ Sertoliform elements with solid islands at this ovarian site are rare in reported human ${ }^{9-12}$ but common in canine $^{13-14}$ androblastomas and were probably outgrown by the other and more diffuse component.

The Wolffian nature of the ovarian tumours is inferred from resemblance to other reported tumours of Wolffian structures, mainly Gartner's duct, paroophoron and epoophoron in the female and seminal vesicles, vas deferens, epididymis and efferent ductules in the male. The prototypes of case 2 and the second area of case 1 are the broad ligament tumours $^{1-3}$ whilst other areas of case 1 repeat other Wolffian origins. Reported cervical Wolffian tumours, variously designated, show four main patterns. These are:

(i) featureless cubical epithelial ducts separated by poorly cellular stroma, ${ }^{15-22}$ as in the first area of case 1 ;

(ii) clusters of apposed small ducts, either alone or see (iii); ${ }^{15-20 ~ 23-25}$

(iii) combined with solid islands and cords;21 26 (case 5)

(iv) intralocular woven adenopapillary formations; 17202223

In Nicholson's Wolffian adenoma of the broad ligament ${ }^{27} 28$ similar structures project into a cyst.

In the male, papillary cystadenomas of the epididymis show a similar pattern range, blurred by swollen clear cells, which may not be present throughout. ${ }^{29} 30$ Somewhat similar to (iii) was a single tumour of the spermatic cord ${ }^{31}$ and some seminal vesicle carcinomas resemble (iv) ${ }^{32} 33$ but they vary greatly ${ }^{34-36}$ and are poorly illustrated.

As to the fourth area of case 1, three cervical tumours ${ }^{183738}$ and a vaginal tumour ${ }^{39}$ have been reported with endometrioid glands, but resemblance to mucosal tumours makes evaluation difficult. Two others combined such glands with solid areas. ${ }^{22} 25$ One contained structures like annular tubules ${ }^{25}$ and one broad ligament tumour Sertoliform cords. ${ }^{3}$ Both formations sometimes occur in tumours of unrelated compound glands. Finally, some of the patterns would not be out of place in renal adenomas and adenocarcinomas ${ }^{40}$ or in a nephroblastoma, of which three questionable ovarian cases have been reported. ${ }^{41}$

The pleomorphism of case 1 reflects both the foregoing pattern range and the mitotic count. Characteristic tumour patterns may not develop if proliferation is either too great or too slight. The relevance of the latter is seen in the endometrioid ovarian tumours which mimic a simpler non-ovarian prototype. In these, benign forms are paradoxically rare, ${ }^{4243}$ probably because they develop no characteristic pattern and are classed as "serous." Three reported 4445 and five personally studied cases have shown transitions from "serous" adenofibroma to endometrioid carcinoma. Similarly, the simplest form of Wolffian tumour is of non-specific "serous" type (Fig. 1). With increasing proliferation it may then develop the "Scully patterns" of Figs. 2-4, what may 


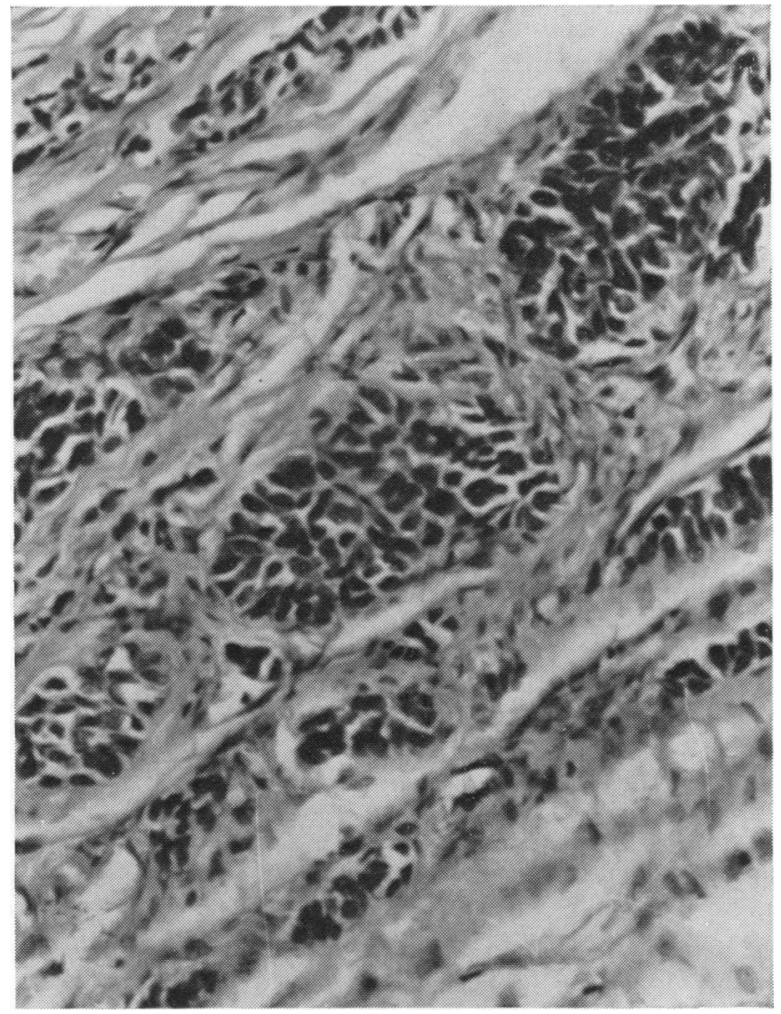

Fig. 12 Case 2. Collagenised seam at junction of tumour and ovary with Sertoliform cords and solid islands. Haematoxylin and eosin $\times 255$

be called (after their earliest full description) the "Meyer patterns" of Figs. 5-8, and the rest which need further clarification.

Whilst the tumours might develop from native or displaced Wolffian cells, ${ }^{12} 46$ they more probably express the quasiembryonic plasticity of ovarian tissue. ${ }^{47}$ This increases in neoplasia, producing mainly the patterns of other urogenital tissues and their tumours, which are used as prototypes. Their range and limits seems to be those of their ancestral intermediate mesoderm. ${ }^{8} 4849$ This directly produces the Müllerian duct and its derivatives, the gonads of both sexes, the adrenal cortex and the nephric structures, and so ex hypothesi may the ovary. Ovarian tumours of Müllerian and gonadal (sex cord/stromal) type are well established. ${ }^{50}$ The evidence that lipid cell tumours, which are mostly of stromal origin, 8 may acquire adrenal cortical identity attested by evidence of adrenal function is suggestive. ${ }^{51}$ With Wolffian tumours uncertainty as to what they should look like allowed many entities to be so identified on insufficient grounds. ${ }^{1}$ The prototypes of the present tumours are definite but rare and variable, partially confirming the foregoing hypothesis when reproduced in ovarian tumours.
The susceptible ovarian region is probably hilar, in view of the intrusion of case 1 into the mesovarian and case 2 into the broad ligament as well as the tumour reported in the rete ovarii. ${ }^{2}$ Rete tumours are various ${ }^{5253}$ but mostly separate from the ovary. Though embryonic rete develops within the gonadal perimeter, it extends into the mesovarium at an early stage. ${ }^{54}$ Part may however, retain or regain a hilar ovarian site to form the medullary canals, ${ }^{55} 56$ and produce a largely intra-ovarian mass.

The microscopic variability, marked in case 1 and slight in case 2 (Fig. 12), contrasts with reported broad ligament tumours. The Wolffian prototypes reviewed suggest that it could become greater, making confusion with many other tumours possible. At present the most likely to be confused are serous tumours (Figs. 1, 5, 6) and arrhenoblastomas (Figs. 3, 7, 9) themselves of very variable appearance. ${ }^{1248}$ Inactive areas are probably indistinguishable from those of serous tumours, but divergencies appear with epithelial proliferation. In serous tumours there is increased papillary sprouting and the present tumours show complex maze-like, sinuous and gyriform patterns. The scanty cytoplasm shows virtually no tendency to differentiate into secretory and ciliated forms. This is common in 
serous tumours and in mesonephric tubules, though not the duct, ${ }^{56}$ Finally, the PAS-positive basement membrane was sharp and generalised, whilst in serous tumours it is more local. ${ }^{57}$

The presence of a sharp PAS-positive basement membrane (PBM) in reported Wolffian tumours ${ }^{1} 225$ may have diagnostic value. In a study of 77 ovarian tumours including serous, endometrioid, mucinous, mixed mesodermal and androblastomatous, the PBM when present was relatively less sharp and consistent. It was often well developed in areas with proliferating and well organised epithelium, but faint or absent with low epithelium, in diffuse areas and in all mucinous tumours. Elastic staining ${ }^{4}$ may also be of value. It showed areas of fine network in both Wolffian cases, of coarse network in some other tumours and only occasional twigs in the remainder. A network is found in some adenomatoid tumours. ${ }^{58}$

A survey of the literature has not revealed any ovarian tumours obviously similar to the present ones but a few with possible affinity-for example, for the more glandular areas those of Ingier ${ }^{59}$ case 1, Meyer ${ }^{60}$ case 3 and Zourlas and Jones ${ }^{61}$ case 1 and for Fig. 9 a case reported by Schiller ${ }^{62}$ (pp 408-410).

Minor oestrogen secretion by the ovarian tumour may explain the occasional endometrial mitoses in case 1 , though the tubal epithelium, a less sensitive index, does not support it. None of the cells had an obvious steroidogenic appearance but could possibly aromatise androgens.

The author is much indebted to Dr Eadie Heyderman for her immunoperoxidase studies of the tumour masses in case 1; to Drs Robert Young and Robert Scully for examining sections of these tumours, a provisional assent to the identification and information about their own cases; to both the foregoing and to Professor NFC Gowing for confirming the histological non-resemblance of the biliary and ovarian tumours in case 1; to Dr RCB Pugh for sections of a papillary cystadenoma of the epididymis; and to Dr Jack Beilby for a helpful discussion.

\section{References}

${ }^{1}$ Sivathondan Y, Salm R, Hughesdon PE, Faccini JM. Female adnexal tumour of probable Wolffian origin. $J$ Clin Pathol 1979;32:616-24.

${ }^{2}$ Karaminejad MH, Scully RE. Female adnexal tumor of probable Wolffian origin. A distinctive pathological entity. Cancer $1973 ; 31: 671-7$.

${ }^{3}$ Taxy JB, Battifora $H$. Female adnexal tumor of probable Wolffian origin: evidence for a low-grade malignancy. Cancer 1976;37:2349-54.

4 Miller PJ. An elastin stain. Med Lab Technol 1971;28: 148-9.

${ }^{5}$ Heyderman E, Steele K, Ormerod MG. A new antigen on the epithelial membrane: its immunoperoxidase localisa- tion in normal and neoplastic tissue. J Clin Pathol 1979; 32:35-9.

${ }^{6}$ Heyderman E. Immunoperoxidase technique in histopathology: applications, methods and controls. J Clin Pathol 1979;32:971-8.

'Dyson JL, Beilby JOW, Steele SJ. Factors influencing survival in carcinoma of the ovary. Br J Cancer 1971; 25:237-49.

${ }^{8}$ Hughesdon PE. Ovarian lipoid and theca cell tumors; their origins and interrelations. Obstet Gynecol Surv $1966 ; 21: 245-88$.

${ }^{9}$ Lordy C. Estudio histologico de um caso de hermaphroditismo glandular, em que a parte testicular e representada por um seminom. Ann Fac Med S Paulo 1930;5: 95-108.

${ }^{10}$ Goldstine MT. Arrhenoblastoma of the ovary. Report of two cases. Am J Obstet Gynecol 1946;52:123-7.

11 Jobbagyi G. Das Gyandroblastom. Zentralbl Gynaekol $1963 ; 85: 1278-83$

${ }^{12}$ Ireland K, Woodruff JD. Masculinizing ovarian tumors. Obstet Gynecol Surv 1976;31:83-111.

${ }^{13}$ Innes JRM. Neoplastic diseases of the testis in animals. J Pathol Bacteriol 1942;54:485-98.

${ }^{14}$ Cotchin E. Canine ovarian neoplasms. Res Vet Sci 1961; 2:133-42.

${ }^{15}$ Thumim L. Ueber die adenomatöse Hyperplasie am cervicaler Drusenanhang des Gartnerschen Ganges. Archiv für Gynaekologie 1900;61 :15-35.

16 Meyer R. Uber Drüsen, Cysten and Adenom im Myometrium bei Erwachsenen. Zeitschrift für Geburtshülfe und Gynaekologie 1900;42:526-46.

${ }^{17}$ Meyer R. Uber Adenom-und Karzinombildung an der Ampulle des Gartnerschen Ganges Virchows Arch (Pathol Anat) 1903;174:270-94.

${ }^{18}$ Rockstroh H. Adenome, Zysten und Karzinom des Gartnerschen Ganges. Zeitschrift für Geburtshülfe und Gynaekologie 1935;112:95-108.

19 Rust W. Adenom des Gartnerschen Ganges. Archiv für Gynaekologie 1936;162:350-3.

20 Wolfe SA. Gartner's duct lesions of the cervix. Am J Obstet Gynecol 1940;39:312-22.

${ }^{21}$ Huffman JW. Mesonephric remnants in the cervix. Am J Obstet Gynecol 1948;56:23-40.

${ }^{22}$ Mackles A, Wolfe, Neigus I. Benign and malignant mesonephric lesions of the cervix. Cancer 1958;11: 292-305.

${ }^{23}$ Meyer R. Beitrag zur Kenntnis des Gartnerschen Ganges beim Menschen. Zeitschrift für Geburtshülfe und Gynaekologie 1907;59:234-62.

${ }^{24}$ Reeb M. Adénome du canal de Gartner. Gynécol Obstét 1937;36:401-7.

${ }^{25}$ McGee CT, Cromer DW, Greene RR. Mesonephric carcinoma of the cervix-differentiation from endocervical carcinoma. Am J Obstet Gynecol 1962;84: 358-66.

${ }^{26}$ Novak E, Woodruff JD, Novak ER. Probable mesonephric origin of certain female genital tumors. Am J Obstet Gynecol 1954;68:1222-42.

${ }^{27}$ Nicholson GW. The importance of congenital malformations in tumour formation. Guys Hospital Reports 1923; 3:37-64.

${ }^{28}$ Nicholson GW de P. Studies on tumour formation London: Butterworths, 1950:92-3.

${ }^{29}$ Grant SM, Hoffman EF. Bilateral papillary adenomas of the epididymides. Arch Pathol Lab Med 1963;76:620-5.

${ }^{30}$ Price EB. Papillary cystadenoma of the epididymis. A clinicopathologic analysis of 20 cases. Arch Pathol Lab Med 1971 ;91:456-70.

${ }^{31}$ Teilum G. Histogenesis and classification of mesonephric tumors of the female and male genital system and 
relationship to benign so-called adenomatoid tumors (mesotheliomas). Acta Pathol Microbiol Scand 1954;34: 431-81.

32 Dalgaard JB, Giersten JC. Primary carcinoma of the seminal vesicle. Acta Pathol Microbiol Scand 1956;39: 255-67.

${ }^{33}$ Ewell GB. Seminal vesicle carcinoma. J Urol 1963;89: 908-12.

${ }^{34}$ McNally A, Cochems FM. Primary carcinoma of the seminal vesicles. J Urol 1936;36:532-7.

${ }^{35}$ McCrea LE. Primary carcinoma of the seminal vesicles. Differentiation from rectal and extrarectal carcinoma and comparative study. JAMA 1948;136:679-82.

${ }^{36}$ Bagley DH, Javadpour N, Witebsky FG, Thomas LB. Seminal vesicle cyst containing a mesonephroid tumor. Urology 1975;5:147-51.

${ }^{37}$ Danneel H. Adenocarcinom der portio vaginalis uteri. Archiv für Gynaekologie 1935;159:395-403.

${ }^{38}$ Buntine DW. Adenocarcinoma of the uterine cervix of probable Wolffian origin. Pathology 1979;11:713-8.

${ }^{39}$ Spencer HR. Adenoma of the vaginal fornix simulating cancer of the cervix. Journal of Obstetrics and Gynaecology of the British Empire 1923;30:44-6.

${ }^{40}$ Bennington JL, Beckwith JB. Tumors of the kidney renal pelvis and ureter. Atlas of Tumor Pathology, 2nd series, fascile 12. Washington DC: Armed Forces Institute of Pathology, 1975.

${ }^{41}$ Fruhling L, Blum E, Le Gal Y. A propos de trois cas de tumeurs ovariennes dysgénétiques primitives à caractères métanéphrogènes. J Urol Nephrol (Paris) 1954;60: 201-7.

42 Russell P. The pathological assessment of ovarian neoplasms. I: Introduction to the common "epithelial" tumours and analysis of benign "epithelial" tumours. Pathology 1979;11:5-26.

${ }^{43}$ Russell P. The pathological assessment of ovarian neoplasms. II. The proliferating 'epithelial' tumours. Pathology 1979;11:251-82.

${ }^{44}$ Bamforth J, Dempster KR, Garland GW. Brenner tumours of the ovary. A report of 2 cases presenting unusual features. Journal of Obstetrics and Gynaecology of the British Empire 1956;63:344-8.

${ }^{45}$ Scully RE, Richardson GS, Barlow JF. The development of malignancy in endometriosis. Clin Obstet Gynecol 1966;9:384-411.

46 Przybora LA. Histogenesis of ovarian epithelial tumors; introducing a new group-“gonado-nephric tumors". Acta Med Pol 1972;13:329-57.

${ }^{47}$ Mossman HW. The embryonic nature of the adult ovary, In: Engle ET, ed. Studies on testis and ovary, eggs and sperm. Springfield, Illinois: Thomas, 1952:196-205.
${ }^{48}$ Hughesdon PE. Fraser IT. Arrhenoblastoma of ovary. Case report and histological review. Acta Obstet Gynecol Scand 1953;32, suppl 4.

${ }^{49}$ Hughesdon PE. Structure and origin of ovarian tumours, In: Kellar RJ, ed. Modern trends in gynaecology, series 3. London: Butterworths, 1963:23-37.

${ }^{50}$ Serov SF, Scully RE, Sobin LH. Histological typing of ovarian tumours. Geneva: World Health Organisation, 1973.

${ }^{51}$ Motlik K, Starka L. Adrenocortical tumour of the ovary. (A case report with particular stress upon morphological and biochemical findings). Neoplasma 1973;20: 97-110.

52 Stange H-H. Ein Beitrag zur normalen und pathologischen Anatomie des Rete ovarii. Zentralbl Gynaekol 1956;78: 81-5.

${ }^{53}$ Stohr G. The relationship of the Brenner tumor to the rete ovarii. Am J Obstet Gynecol 1956;72:389-99.

s4 Wilson KM. Origin and development of the rete ovarii and the rete testis in the human embryo. Contrib Embryol 1926;17:69-88.

sb Joachimovits R. Markstränge, Markcysten und Ovarpapillome. Archiv fur Gynaekologie 1935:159:1-11.

so Gardner GH, Greene RR, Peckham BM. Normal and cystic structures of the broad ligament. Am J Obstet Gynecol 1948;55:917-39.

57 Purola E. Serous papillary ovarian tumours. A study of 233 cases with special reference to the histological type of tumour and its influence on prognosis. Acta Obstet Gynecol Scand 1963;42: suppl 3.

58 Ragins AB, Crane RD. Adenomatoid tumors of the Fallopian tube. Am J Pathol 1948;24:933-46.

${ }^{59}$ Ingier A. Casuistische und kritische Beiträge zum sogenannten "Folliculoma ovarii." Archiv für Gynaekologie 1907;83:545-65.

- Meyer R. Das Adenoma tubulare ovarii carcinomatosum und die Beziehung des tubulären Ovarialadenome zu embryonalen Organresten. Stud Pathol Entwickl 1920;2: 93-115.

1 Zourlas PA, Jones HW, Jr. Stein-Leventhal syndrome with masculinizing ovarian tumor. Report of 3 cases. Obstet Gynecol 1969;34:861-6.

${ }^{62}$ Schiller W. Parvilocular tumors of the ovary. Arch Pathol Lab Med 1943;35:391-413.

Requests for reprints to: Dr PE Hughesdon, Department of Morbid Anatomy, School of Medicine, University College London, University Street, London WC1E 6JJ, England. 